\title{
Customer Satisfaction Assessment by Online Shopping Service: A Case Study of Serbia
}

\author{
Tanja KAURIN*, Aleksandar BOŠKOVIĆ
}

\begin{abstract}
Markets face a constant dilemma regarding factors that can affect customer satisfaction with online shopping. The solution to this dilemma is especially important for those markets where online shopping is not sufficiently represented, such as the Serbian market. Therefore, it is necessary to analyse the relationship of customer satisfaction and the various factors. The aim of the research was to determine the effect of certain factors of online shopping on customer satisfaction in the Serbian market. Accordingly, a research methodology and a measuring instrument were developed and implemented. The empirical research was conducted based on the survey questionnaire and the representative sample of 340 customers which made online purchases in Serbia for over two years. The conceptual model and the survey questionnaire included 20 variable items grouped into five basic dimensions: website quality, information availability, security, privacy and reliability. The validity of the developed methodology and the measurement instrument was tested using confirmatory factor analysis. The obtained results showed that, according to survey dimensions, in the case of Serbian market, users are not satisfied with online shopping services. It has been confirmed that satisfaction depends on the age structure of the customer, but it does not depend on the gender.
\end{abstract}

Keywords: customer satisfaction; information availability; online shopping; privacy; reliability; security; Serbia; website quality

\section{INTRODUCTION}

Over the past decade the online shopping has reported a very intensive growth, which will continue with an even stronger trend in the coming years. The extent to which customers will replace traditional shopping method with an online one depends on a number of factors and circumstances. The transition to a more fashionable method of shopping creates initially a lot of concern for many customers in relation to the security, reliability, private information protection, online fraud, inadequate quality of the delivered product, unsuccessful delivery, etc. Once the initial concern has been overcome, the key factors for further development of online shopping become service quality and customer satisfaction.

The concepts of customer satisfaction and customer retention have become increasingly important to online business. When the customer is satisfied with a certain online shopping service, he will use it more often and more intensely [1] and, over the time, he will become a regular and loyal customer. Customer retention is a key requirement for obtaining competitive advantage on the market [2]. It is necessary to foster satisfied and loyal customers. Customer satisfaction is affected by many different factors and it is crucial to identify what these key factors are and how they could affect customer satisfaction in online shopping [3].

This paper deals with customer satisfaction analysis. The aim of the paper is to establish the relationship between the customer satisfaction and specific online shopping factors by carrying out an empirical analysis of the Serbian market.

In addition to the introduction and the conclusion, the paper contains three more sections. The main research question together with research hypotheses are defined in the second section. The methodology and the research model are presented in the third section. The results of the research are presented and analysed in the fourth section.

\section{DEFINITION OF THE PROBLEM AND RESEARCH HYPOTHESIS}

Customer satisfaction is the relationship between the expected and observed online shopping service quality.
The customer will be satisfied when the service fulfils or exceeds its expectations [4]. Customers would purchase again only if they are satisfied, i.e. if the service provided reaches or exceeds their expectations [5]. Due to the importance of customer satisfaction, a large number of researches on this issue have been conducted on developed markets. Studies have shown that this way of shopping provides more satisfaction to modern customers who are looking for convenience and speed, compared to the classic systems [6]. In less developed markets, such as the Serbian market, there is no significant research on this topic. This research stems from the need to fill in this research gap by developing an appropriate measurement instrument for evaluation of the customer satisfaction in online shopping service in Serbia. Hence, the scientific contribution of this paper lies in the fact that the developed measuring instrument embeds dimensions and items that correspond to a specific online shopping context. The focus of this research is the online purchase of material products. The measuring instrument has been tested and applied in an empirical research on the Serbian market. Accordingly, the following main research null hypotheses were defined:

$\mathrm{H} 1$ - There is no statistically significant relationship between customer satisfaction and online shopping service level.

The first question is what are the key factors affecting the customer satisfaction. Customer satisfaction factors represent business indicators and serve as guidelines for future improvements [5]. Key factors and satisfaction dimensions in this paper were identified on the basis of the literature review dealing with this topic. Numerous authors have analysed the various online shopping service factors and dimensions affecting the customer satisfaction. For example, 11 dimensions of electronic service quality were identified as [7]: reliability, access, ease of navigation, efficiency, responsiveness, flexibility, price knowledge, assurance/trust, security site aesthetics, and personalization. An overview of the literature related to the development of the electronic service quality has shown that different dimensions are used in surveys on customer satisfaction in online shopping. However, most papers use dimensions, such as: reliability/fulfilment, responsiveness, 
web design, ease of use/usability, privacy, security, and information quality [8].

On the basis of relevant literature, five dimensions of the online shopping of material products are defined: website quality, information availability, security, privacy and reliability. Accordingly, five subhypotheses are also defined within the main research hypothesis. The following discussion gives a detailed description of the dimensions and subhypotheses of the research.

The website quality is cited as a key dimension that affects customer satisfaction in a large number of studies [8]. The website quality, design and content play an important role in attracting and retaining customers [9]. According to [10], the website has a similar effect on the customer as the physical appearance of the store in traditional shopping. The aesthetic component of the website, the content transparency and the online catalogue structure are very important [11]. In [9], important items for customer satisfaction are the website availability, the ease of use, and the visual presentation of the product. Some authors state that online shopping can be viewed as "fun", where important dimensions are the visual appeal, innovation, and the flow of movement through the website [12]. Content layout must be simple and feature an easy way to navigate, order processing, appropriate personalization, search of information and product selection [13]. Based on the presented, the following research null subhypothesis is defined:

H1.1 - There is no statistically significant relationship between customer satisfaction and web site quality.

Many authors believe that the amount and credibility of the information are key elements in securing the service quality of online shopping. The amount of information is the ability to access relevant information at the time of online shopping (e.g. price comparison), while credibility implies the degree of customer confidence according to information provided by online sellers [14]. During online shopping, the customer wants to receive compatible, accurate and reliable information [15]. Providing relevant information can help online vendors to eliminate customers' concerns and fears about a particular product or online shopping [16]. Instead of "byte sound", customers want access to complete information that will enable them to make the right decisions about a product, service, or purchase [17]. Interactive tools for online comparison of products and services are considered as important tools for obtaining information. They make it easier for customers to make online shopping decisions and make them more satisfied [18]. In [19], product information, in terms of quantity and quality, has been identified as components of e-satisfaction. Having in mind the above facts, the following research null subhypothesis has been defined:

H1.2 - There is no statistically significant relationship between customer satisfaction and information availability.

Website security is defined as the ability of a website to protect customer's personal information from any unauthorized disclosure during an electronic transaction [20]. Security is considered an important factor that online shopping customers take seriously [21]. This is because security and privacy issues play an important role in creating trust in the internet transaction [22]. Security can be divided into two parts: the first part refers to the security of data and transactions, while the other part is directed at the customer authenticity [20]. For the online shopping security, a good organization of the process with precise data access procedures is crucial, as well as a security policy, an effective checking technology and certainly a human factor [23]. If a company cannot ensure data security, then it is certain that it does not have a corresponding level of corporate responsibility [24]. Therefore, secure web sites have reliable and satisfied customers. Based on the above, the following research null subhypothesis has been defined:

H1.3 - There is no statistically significant relationship between customer satisfaction and service security.

Privacy can be a major problem that discourages customers from online shopping, as customers are concerned that sellers will mislead them and misuse their personal information, in particular their credit cards. Since online shopping usually involves paying by using debit or credit cards, customers sometimes direct their attention to seller information in order to protect themselves [25]. Customers tend to buy a product from a seller whom they trust or a well-known product brand [26]. In online shopping, trust is one of the most critical factors that affects the success or failure of online sellers [27]. For example, the report indicates that $70 \%$ of US online shopping users are seriously worried about the misuse of their personal data and transaction security [28]. In [29] attention is focused on privacy and security issues and it is found that $61 \%$ of respondents would have continued with online transactions if their privacy and personal data had been protected. This shows that privacy protection in online shopping is one of the important dimensions which the customer takes into account when deciding on online shopping. Online services that have good privacy protection have reliable and satisfied customers. Based on the above, the following research null subhypothesis has been defined:

H1.4 - There is no statistically significant relationship between customer satisfaction and privacy protection.

In most papers and studies reliability is cited as a key dimension that affects the online customer satisfaction [10, 14]. In online shopping, the customer expects an appropriate standard of reliable delivery to be achieved. He expects efficient and reliable purchase and delivery at all stages from processing orders and transactions to delivery of the product. The reliability refers to the fulfilment of the guaranteed delivery conditions, that is, that the material product is delivered exactly on time, to the appropriate place, with the expected quality [30]. Delivery time is very important for online customers and they expect the service to be time reliable [31]. Reliability is associated with the observed risk of online shopping [32]. The lack of reliable, fast and accurate service causes a negative perception and dissatisfaction of customers. Reliability is an important factor of the service quality that creates customer satisfaction [33]. Based on the above, the following research null subhypothesis has been defined:

H1.5 - There is no statistically significant relationship between customer satisfaction and reliability.

On the Serbian market, about $33 \%$ of customers use online shopping service. Nearly half of Serbian online customers buy clothes, shoes and jewellery, while about a third of them buy the devices and equipment [34, 35]. 
Customers have different age structure. Studies have shown that younger customers, with higher levels of education and higher incomes use more often online shopping services [34]. The assumption is that customers of different ages have different expectations and perceptions of online shopping service quality. On the other hand, it is interesting to examine the customer perceptions of the online services quality in terms of gender. In accordance with the above, two other research null hypotheses have been defined:

H2 - Customer satisfaction with online shopping service does not depend on the age of the customer.

H3 - Customer satisfaction with online shopping service does not depend on the gender of the customer.

After a brief description of the research question and the definition of the main research hypotheses, a specific methodology was developed for carrying out the empirical analysis and testing hypotheses.

In the next section of the paper, the research methodology is described and then the results are presented and analysed.

\section{RESEARCH METHODOLOGY}

The empirical research includes three main methodological steps: selection of a representative sample, definition of the survey measurement instrument and model testing.

\subsection{Sample Selection}

The sample was selected in accordance with the research objective. The sample consists of customers of material products that intensively used online shopping services on the Serbian market in the past two years. In accordance with the research objectives, customers who bought different types of products through online services are not included.

Customers were selected from the Post of Serbia database which, via Post express service, delivers shipments purchased through various online shopping services. Customers of different age, gender, education and with various experience in using online shopping services were selected and surveyed. A web-based survey method was used for data acquisition in accordance with the guidelines set out in the paper [16]. The Post of Serbia has acknowledged the importance of this research and gave its support and assistance during the survey phase. Accordingly, consumers' contacts and e-mail addresses were legally obtained from their database. The Post of Serbia informed the customers about the motives and the relevance of the research and pointed out the importance of completing the web survey. Afterwards, the authors contacted customers by e-mail and asked them to complete the survey questionnaire online. During the survey, respondents were reminded and encouraged to fill out the survey through a friendly reminder. This has significantly increased customer response, and thus the number and quality of completed web survey questionnaires. Out of 850 sent emails, 30 were not delivered and therefore were deleted from the sample, resulting in a net potential sample of 820 respondents. Out of 820 potential questionnaires, 369 questionnaires were filled in (45\%): 29 questionnaires were only partially completed and 340 (41.46\%) valid questionnaires remained.

As proposed in [36], the competence of the respondents is assessed on the basis of their personal data. In order to check for the respondent bias, a comparison of the response from the early and late stage of the research was made. In fact, all received questionnaires are divided into four equal groups, by respond date. In order to evaluate the difference between the responses received in certain test periods, $t$-tests were performed. It was found that there was no statistically significant difference in responses, which led to the conclusion that there was no significant respondent bias.

\subsection{Measuring Instrument Determination}

There is no clear consensus in the literature on the measuring instrument, dimensions and items to deploy for evaluation of the user satisfaction with online shopping service [8]. Most of the papers developed and used measuring instruments with different dimensions and items. Among these, certain dimensions appear in a large number of papers, e.g.: reliability, website design, security, privacy, information availability etc. [37]. Additional dimensions used in other researches depend mainly on the industry and the context of online shopping being researched [38].

Essentially, it is necessary to adapt each measurement instrument to the specific industry and market. Accordingly, this research paper developed a measuring instrument that includes dimensions of online services regularly used in the literature together with items that correspond to online purchases of material products specific to the Serbian market [34, 35].

The measuring instrument and the questionnaire are defined in three sections. The first section contains questions related to general user information. The second section contains questions about expectations while the third section refers to the observations of online shopping service users. A questionnaire with 20 items was constructed, classified into five basic dimensions:

Website quality ( $V 1$ - website design is attractive, $V 2$ - website content is detailed and transparent, $V 3$ - website is user-friendly, $V 4$ - website is easy to find);

Information availability ( $V 5$ - information can be effectively reviewed and exchanged, V6 - customer questions and opinions can be immediately sent online to the appropriate departments, $V 7$ - information can be obtained on time, $V 8$ - questions, opinions and answers can be easily lost in the communication chain);

Security ( $V 9$ - transaction security, $V 10$ - data access without permission is not possible, $V 11$ - original message content remains unchanged during or after online transactions, $V 12$ - technology provides efficient user action checking);

Privacy ( $V 13$ - customer personal and financial information protection, $V 14$ - technology can effectively prevent theft of identity and data, $V 15$ - payment terms and delivery conditions are protected, $V 16$ - it is not possible to use a fake name and identity);

Reliability ( $V 17$ - online technologies are efficient in preserving accurate data values, $V 18$ - system is able to efficiently process a large number of transactions, 
connections, and commands, $V 19$ - purchased products/services will be delivered within the time limit, $V 20$ - delivered products/services will be of the appropriate quality).

On the basis of the Likert scale, respondents assessed expectations and perceptions by individual dimensions and items. Respondents gave ratings on a scale of 1 - very low expectation (perception) level - up to 7 - very high expectation (perception) level.

\subsection{Model Testing}

Testing and validation of the measuring instrument were performed using factor analysis and metric characteristics such as: reliability, convergence and discriminant validity. The suitability of the sample for the use of factor analysis was previously evaluated. One of the preconditions for applying the analysis is the correlation between the source variables. The correlation test found that the Kaiser-Meyer-Olkin measure of sampling adequacy was 0.846 and the Bartlett's test of sphericity (647.385) was significant at $1 \%$, indicating that the sample was fit for factor analysis.
A confirmatory factor analysis (CFA) was carried out with the aim of testing empirically and verifying the factor structure of the measuring instrument [39]. The obtained results (Tab. 3) show that each of the five dimensions explains a high percentage of total variation (from $64.26 \%$ for security to $76.169 \%$ for information availability). In such situations, the model explaining over $60 \%$ of the total variance is considered acceptable. The measuring instrument reliability was determined via Cronbach's alpha coefficient whose value ranges from 0.736 to 0.891 (Tab. $1)$.

Given that all values are significantly greater than 0.7 , the reliability condition is satisfied and five selected dimensions can be defined as key factors [40]. The measuring instrument convergence validity and dimensionality is tested over factor loadings, which indicate the relationship between factors and associated variables. The standard factor loadings in all cases are over 0.5 , which provides support for the convergent validity of dimensions [41]. The statistical significance of factor loadings is estimated and all values were found to be greater than 10 (for $p<0.001$ ), indicating a strong relationship between the variables within the observed factors (Tab. 1).

Table 1 Factor loadings ( $t$-values), reliability and total variation of measurement scale

\begin{tabular}{|c|c|c|c|c|c|}
\hline \multirow{2}{*}{ Abbreviation of measured variable } & \multicolumn{5}{|c|}{ Dimensions } \\
\hline & Website quality & Information availability & Security & Privacy & Reliability \\
\hline$V 1$ & 0.815 & & & & \\
\hline$V 2$ & $0.77\left(11.65^{\mathrm{a}}\right)$ & & & & \\
\hline$V 3$ & $0.787(23.43)$ & & & & \\
\hline$V 4$ & $0.76(14.67)$ & & & & \\
\hline$V 5$ & & 0.835 & & & \\
\hline V6 & & $0.782(17.22)$ & & & \\
\hline$V 7$ & & $0.835(18.15)$ & & & \\
\hline$V 8$ & & $0.797(12.23)$ & & & \\
\hline$V 9$ & & & 0.758 & & \\
\hline$V 10$ & & & $0.862(15.53)$ & & \\
\hline$V 11$ & & & $0.7568(22.72)$ & & \\
\hline$V 12$ & & & $0.780(14.44)$ & & \\
\hline$V 13$ & & & & 0.823 & \\
\hline$V 14$ & & & & $0.978(18.98)$ & \\
\hline$V 15$ & & & & $0.766(13.53)$ & \\
\hline$V 16$ & & & & $0.834(22.48)$ & \\
\hline$V 17$ & & & & & 0.797 \\
\hline$V 18$ & & & & & $0.808(18.51)$ \\
\hline$V 19$ & & & & & $0.746(11.68)$ \\
\hline$V 20$ & & & & & $0.832(10.31)$ \\
\hline Variance extracted / \% & 76.169 & 66.14 & 64.26 & 71.91 & 70.23 \\
\hline Cronbach's alpha & 0.891 & 0.796 & 0.824 & 0.736 & 0.812 \\
\hline
\end{tabular}

${ }^{\mathrm{a}} t$-values shown in parentheses. All are significant $(p<0.001)$

${ }^{\mathrm{b}}$ Values are not available for the fixed factor loadings

Table 2 Correlations and standard errors among factors

\begin{tabular}{|c|c|c|c|c|}
\hline & Website quality & Information availability & Security & Privacy \\
\hline Information availability & $-0.224(0.002)^{*}$ & & & \\
\hline Security & $-0.143(0.01)$ & $0.295(0.018)$ & & \\
\hline Privacy & $0.182(0.02)$ & $0.274(0.023)$ & $0.322(0.02)$ & \\
\hline Reliability & $-0.197(0.05)$ & $-0.231(0.087)$ & $-0.256(0.03)$ & $-0.187(0.04)$ \\
\hline
\end{tabular}

* Note: Confidence intervals around factor correlations indicate that in general factors are not distinct from each other

The variables and factors represent a unique concept and the unidimensionality condition of the measurement factors is fulfilled. The discriminatory validity of the measurement scale is tested by correlation among measurement factors (Tab. 2). There is a weak correlation between the factors (from 0.143 to 0.295 ) indicating that they are significantly different from each other. Hence, discriminatory validity was confirmed [40].
Since the results of the conducted tests confirmed the validity and convenience of the measuring instrument on the observed sample, the satisfaction of the online shopping service users was assessed, i.e. the determination and testing of the gap between expectations and perceptions. The obtained results are shown in the next section of the paper. 


\section{$4 \quad$ RESULTS ANALYSIS AND DISCUSSION}

The online shopping service user satisfaction is estimated through the gap between observed and expected values per measurement scale. If the gap is positive, it is considered that the user is satisfied, and if the gap is negative then the user is considered not to be satisfied with the online shopping service. Tab. 3 shows the average expected and observed values as well as the gap determined by the five basic dimensions of the measuring instrument.

As previously determined using the KolmogorovSmirnov test, all variables have a normal distribution. Therefore, a $t$-test was performed in order to determine the statistical significance of the identified gap. According to the obtained results and $t$-values ( $t$-values are greater than 10 for $p<0.001)$, it is concluded that there is a significant difference between the expected and observed online shopping service level, in all dimensions of the measuring instrument. For each dimension, the observed values are less than expected, indicating an unsatisfactory online shopping service level. It is concluded that the hypothesis $\mathrm{H} 1$ and all null sub-hypotheses H1.1-H1.5 are confirmed. The total average value of the gap is -1.152 . The greatest gap value is for the information availability $(-1.904)$, and the lowest for the website quality $(-0.577)$. It means that the lowest online shopping service level refers to the information availability (hypothesis H1.2), and the highest to the website quality (hypothesis H1.1).

Table 3 Gap between user perceptions and expectations

\begin{tabular}{|c|c|c|c|c|c|}
\hline Dimensions & Perception $(P)$ & Expectations $(E)$ & $\operatorname{Gap}(P-E)$ & $t$-value & $p$-value \\
\hline Website quality & 5.870 & 6.447 & -0.577 & 22.84 & 0.001 \\
\hline Information availability & 4.548 & 6.452 & -1.904 & 17.04 & 0.001 \\
\hline Security & 4.232 & 5.164 & -0.932 & 11.75 & 0.001 \\
\hline Privacy & 4.883 & 5.597 & -0.714 & 16.98 & 0.001 \\
\hline Reliability & 3.713 & 5.347 & -1.634 & 24.23 & 0.001 \\
\hline Total gap & 4.649 & 5.801 & -1.152 & 14.74 & 0.001 \\
\hline
\end{tabular}

The results are in line with conclusions of several studies that dealt with different markets across the world. For example, surveys done for the Greek market showed that customer satisfaction directly depends on the information availability and the user interface quality [42]. In the Malaysian market, the key impact on consumer satisfaction have information availability, reliability and website design [32]. Studies of the Chinese market show that information quality, website design, security and payment methods are crucial for customer satisfaction [18]. According to [43], offering a wide range of products and providing complete information leads to consumer satisfaction in the South African market. The results of the research on the Taiwanese market show that the customer satisfaction with online shopping directly depends on the factors such as information quality, system quality, service quality, product quality, delivery quality, and perceived price [44].

Having determined that there is a significant difference between the expected and observed level of online shopping services on the entire sample, it was necessary to determine the perception of individual market segments.

The dependence of satisfaction on the age structure of users was examined by considering three market segments: TS1 - users under 30 years of age, TS2 - users aged 30-50 years and TS3 - users older than 50 years. The average perception and gap by the basic dimensions of the measurement scale were determined. The statistical significance of the differences in these quantities by market segments was tested by ANOVA analysis (Tab. 4).

Table 4 User perceptions and realized gap according to the age structure of users

\begin{tabular}{|c|c|c|c|c|c|}
\hline \multirow{2}{*}{\multicolumn{2}{|c|}{ Measurement scale dimension }} & \multicolumn{3}{|c|}{ Market segment } & \multirow{3}{*}{$\begin{array}{c}F \text {-value } \\
7.24 \\
8.42\end{array}$} \\
\hline & & \multirow{2}{*}{$\begin{array}{c}T S 1 \\
\text { users under } 30 \text { years of age } \\
5.59 \\
-1.37\end{array}$} & \multirow{2}{*}{$\begin{array}{c}\text { TS2 } \\
\text { users aged } 30-50 \text { years } \\
6.32 \\
-1.97\end{array}$} & \multirow{2}{*}{$\begin{array}{c}T S 3 \\
\text { users older than } 50 \text { years } \\
5.41 \\
-1.65\end{array}$} & \\
\hline Website quality & $\begin{array}{l}\text { Perception } \\
\text { Gap }\end{array}$ & & & & \\
\hline Information availability & $\begin{array}{l}\text { Perception } \\
\text { Gap }\end{array}$ & $\begin{array}{c}5.11 \\
-1.12\end{array}$ & $\begin{array}{c}4.73 \\
-1.75\end{array}$ & $\begin{array}{c}4.17 \\
-1.95\end{array}$ & $\begin{array}{l}8.56 \\
9.95\end{array}$ \\
\hline Security & $\begin{array}{l}\text { Perception } \\
\text { Gap }\end{array}$ & $\begin{array}{c}5.56 \\
-0.95\end{array}$ & $\begin{array}{c}5.19 \\
-0.94\end{array}$ & $\begin{array}{c}4.92 \\
-1.85\end{array}$ & $\begin{array}{l}9.31 \\
8.92\end{array}$ \\
\hline Privacy & $\begin{array}{l}\text { Perception } \\
\text { Gap }\end{array}$ & $\begin{array}{c}6.3 \\
-0.83\end{array}$ & $\begin{array}{c}4.95 \\
-0.76\end{array}$ & $\begin{array}{c}5.2 \\
-0.93\end{array}$ & $\begin{array}{l}7.12 \\
8.65\end{array}$ \\
\hline Reliability & $\begin{array}{l}\text { Perception } \\
\text { Gap }\end{array}$ & $\begin{array}{c}5.65 \\
-0.87\end{array}$ & $\begin{array}{c}4.77 \\
-1.84\end{array}$ & $\begin{array}{c}5.35 \\
-0.95\end{array}$ & $\begin{array}{l}8.23 \\
9.12\end{array}$ \\
\hline
\end{tabular}

A significant difference in the perception of users ( $F$ values range from 7.12 to 9.31 for $p<0.001)$, as well as in the gap ( $F$-values range from 7.95 to 9.95 at $p<0.001)$ was found. Using the least significant difference $(L S D)$ test, the significance of the difference between individual market segments was determined. $F$-value between $T S 1$ and TS2 is $7.35(p<0.001), F$-value between TS1 and TS3 is 9.35 ( $p$ $<0.001)$, and $F$-value between TS2 and TS3 is 7.68 ( $p<$ 0.001 ). Based on the results of the ANOVA analysis, it is concluded that the online shopping service level perception and satisfaction depend directly on the age of the user rejecting the null hypothesis $\mathrm{H} 2$.

Further analysis tested whether the customer satisfaction in online shopping depends on the gender of the user. The analysis of the perception gap for male and female customers was performed (Tab. 5). The ANOVA analysis showed that there is no significant difference between these two customer groups. $F$-values range from 1.52 to $2.58(p<0.001)$ in the perception, and from 2.47 to $3.37(p<0.001)$ in the gap. These results confirm the $\mathrm{H} 3$ null hypothesis and therefore it can be concluded that 
customer satisfaction in online shopping does not depend on the gender of the user.

Table 5 User perceptions and realized gap according to the gender of users

\begin{tabular}{|l|l|c|c|c|}
\hline \multirow{2}{*}{ Measurement scale dimension } & \multicolumn{2}{|c|}{ User gender } & \multirow{2}{*}{ F-value } \\
\cline { 3 - 4 } Website quality & Perception & 6.75 & 5.89 & 1.96 \\
\cline { 3 - 4 } & Gap & -0.12 & -0.78 & 2.84 \\
\hline \multirow{2}{*}{ Information availability } & Perception & 6.53 & 6.34 & 2.58 \\
\cline { 3 - 4 } & Gap & -0.26 & -0.95 & 3.37 \\
\hline \multirow{2}{*}{ Security } & Perception & 6.69 & 6.10 & 1.62 \\
\cline { 3 - 4 } & Gap & -0.17 & -1.01 & 2.47 \\
\hline \multirow{2}{*}{ Privacy } & Perception & 6.83 & 5.67 & 2.03 \\
\cline { 3 - 4 } & Gap & -0.09 & -0.98 & 2.97 \\
\hline \multirow{2}{*}{ Reliability } & Perception & 6.15 & 6.75 & 2.42 \\
\cline { 3 - 4 } & Gap & -0.07 & -0.86 & 3.12 \\
\hline
\end{tabular}

\section{CONCLUSION}

Daily growth of the internet and online sales has changed the way of doing business, marketing, and selling products and services. As a result of the development of electronic information sources, the evolution of product and information supply and the new digital era have imposed many business challenges. With the new way of doing business, the user requirements and expectations have been changing. Customers have a growing demand for product vendors and service providers. Service quality and customer satisfaction are key factors of successful business. It is essential that companies constantly observe the user requirements and expectations, find ways to fulfil requests and create satisfied customers. It is necessary for companies to measure user satisfaction and to develop different procedures, models and tools that will be successfully used in real market and economic conditions.

The research developed and carried out in this paper presents an exact contribution to these efforts. The proposed methodology can be successfully used to research and examine various factors and variables that affect the online shopping service user satisfaction.

The results of the research show that website quality, information availability, security, privacy and reliability affect the customer satisfaction. In the case of Serbian market, the application of these dimensions indicates that users are not satisfied with the online shopping service quality. Therefore, these results suggest that key service dimensions need to be improved, such as website quality, information availability, transaction security, privacy and reliability. Moreover, the survey showed that satisfaction also depends on the age structure of customers while the customer expectations and perceptions differ significantly depending on their age. In addition to the factors and dimensions of satisfaction analysed in this paper, in the follow-up research it would be necessary to include other elements such as security, payment method, product delivery costs, etc. In addition, it would be important to research and compare different online shopping services as well as different customer structure on the market.

\section{REFERENCES}

[1] Khalifa, M. \& Liu, V. (2007). Online consumer retention: Contingent effects of online shopping habit and online shopping experience. European Journal of Information Systems, 16(6), 780-792. https://doi.org/10.1057/palgrave.ejis.3000711

[2] Tsai, H. \& Huang, H. (2007). Determinants of e-repurchase intentions: An integrative model of quadruple retention drivers. Information \& Management, 44(3), 231-239. https://doi.org/10.1016/j.im.2006.11.006

[3] Devaraj, S., Fan, M., \& Kohli, R. (2002). Antecedents of B2C Channel Satisfaction and Preference: Validating eCommerce Metrics. Information Systems Research, 13(3), 316-333. https://doi.org/10.1287/isre.13.3.316.77

[4] Khristianto, W., Kertahadi, I., \& Suyadi, I. (2012). The influence of information, system and service on customer satisfaction and loyalty in online shopping. International Journal of Academic Research, 4(2), 28-32.

[5] Alam, S. \& Yasin, N. (2010). An investigation into the antecedents of customer satisfaction of online shopping. Journal of Marketing Development and Competitiveness, $5(1), 71-78$

[6] Yu, T. \& Wu, G. (2007). Determinants of internet shopping behavior: An application of reasoned behavior theory. International Journal of Management, 24(4), 744-762.

[7] Zeithaml, V. A. (2002). Service excellence in electronic channels. Managing Service Quality: An International Journal, 12(3), 135-139. https://doi.org/10.1108/09604520210429187

[8] Ladhari, R. (2010). Developing e-service quality scales: A literature review. Journal of Retailing and Consumer Services, 17(6), 464-477. https://doi.org/10.1016/j.jretconser.2010.06.003

[9] Ranganathan, C. \& Ganapathy, S. (2002). Key dimensions of business-to-consumer web sites. Information \& Management, 39(6), 457-465. https://doi.org/10.1016/S0378-7206(01)00112-4

[10] Sohn, C. \& Tadisina, S. K. (2008). Development of e-service quality measure for internet-based financial institutions. Total Quality Management \& Business Excellence, 19(9), 903-918. https://doi.org/10.1080/14783360802224412

[11] Cai, S. \& Jun, M. (2003). Internet users perceptions of online service quality: A comparison of online buyers and information searchers. Managing Service Quality: An International Journal, 13(6), 504-519. https://doi.org/10.1108/09604520310506568

[12] Loiacono, E. T., Watson, R. T., \& Goodhue, D. L. (2002). WebQual: measure of web site quality. Marketing Educators Conference: Marketing Theory and Applications, 13, 432437.

[13] Cristobal, E., Flavián, C., \& Guinalíu, M. (2007). Perceived e-service quality (PeSQ). Managing Service Quality: An International Journal, 17(3), 317-340. https://doi.org/10.1108/09604520710744326

[14] Fowler, F. J. (2014). Survey research methods. London: Sage Publication.

[15] Collier, J. E. \& Bienstock, C. C. (2006). Measuring service quality in e-retailing. Journal of Service Research, 8(3), 260275. https://doi.org/10.1177/1094670505278867

[16] George, J. F. (2002). Influences on the intent to make Internet purchases. Internet Research, 12(2), 165-180. https://doi.org/10.1108/10662240210422521

[17] Goldsmith, R. E. \& Bridges, E., (2000) E-tailing versus retailing: Using attitudes to predict online buying behaviour. Quarterly Journal of Electronic Commerce, 1(3), 245-253.

[18] Guo, X., Ling, K. C., \& Liu, M. (2012). Evaluating Factors Influencing Consumer Satisfaction towards Online Shopping in China. Asian Social Science, 8(13). https://doi.org/10.5539/ass.v8n13p40

[19] Häubl, G. \& Trifts, V. (2000). Consumer Decision Making in Online Shopping Environments: The Effects of Interactive Decision Aids. Marketing Science, 19(1), 4-21. https://doi.org/10.1287/mksc.19.1.4.15178 
[20] Rehman, C. A., Dost, M. K., \& Illyas, M. (2015). Online Shopping Trends and Its Effects on Consumer Buying Behavior: A Case Study of Young Generation of Pakistan. NG-Journal of Social Development, 5(1), 1-22. https://doi.org/10.12816/0032077

[21] Dwight, S. A. \& Feigelson, M. E. (2000). A Quantitative Review of the Effect of Computerized Testing on the Measurement of Social Desirability. Educational and Psychological Measurement, 60(3), 340-360. https://doi.org/10.1177/00131640021970583

[22] Global B2C E-commerce Report (2016). Retrieved from https://www.ecommercewiki.org/wikis/www.ecomme rcewiki.org/images/5/56/Global_B2C_Ecommerce Report 2016.pdf

[23] Gupta, P. \& Dubey, A. (2016). E-Commerce- Study of Privacy, Trust and Security from Consumer's Perspective. International Journal of Computer Science and Mobile Computing, 5(6), 224-232.

[24] Eisen, O. (2010). Online security - a new strategic approach. Network Security, 2010(7), 14-15. https://doi.org/10.1016/S1353-4858(10)70094-5

[25] Ehsani, Z. \& Ehsani, M. H. (2015). Effect of Quality and Price on Customer Satisfaction and Commitment in Iran Auto Industry. International Journal of Service Sciences, Management and Engineering, 1(5), 52-56.

[26] Eurostat (2015). Statistics Database. Information society statistics. (n.d.). Retrieved from http://ec.europa.eu/eurostat /data/database

[27] Federal Trade Commission (2011). Privacy Leadership Initiative. (n.d.). Retrieved from https://www.ftc.gov/sites/d efault/files/documents/public_comments/preliminary-ftcstaff-report-protecting-consumer-privacy-era-rapid-changeproposed-framework/00369-57987.pdf

[28] Fornell, C. (1992). A National Customer Satisfaction Barometer: The Swedish Experience. Journal of Marketing, 56(1), 6-21. https://doi.org/10.1177/002224299205600103

[29] Global B2C E-commerce Report (2015). Retrieved from http://boletines.prisadigital.com/global $\% 20 \mathrm{~b} 2 \mathrm{c} \% 20 \mathrm{e}-$ commerce\%20report $\% 202015 \% 20$ light.pdf

[30] Jun, M., Yang, Z., \& Kim, D. (2004). Customers perceptions of online retailing service quality and their satisfaction. International Journal of Quality \& Reliability Management, 21(8), 817-840. https://doi.org/10.1108/02656710410551728

[31] Khan A. H., Rahman M. K., \& Ramezanie E. (2013). Accessing the Effectiveness of Online Shopping Among Malaysian Consumers, Australian Journal of Basic and Applied Sciences, 7(7), 603-612.

[32] Alam, S. S. \& Yasin, N. M. (2010). An Investigation into the Antecedents of Customer Satisfaction of Online Shopping. Journal of Marketing Development and Competitiveness, 11(2), 210-216. https://doi.org/10.3846/jbem.2010.10

[33] Alam, S. S., Bakar, Z., Ismail, H. B., \& Ahsan, M. N. (2008). Young Consumers Online Shopping: An Empirical Study. Journal of Internet Business, 5, 81-98.

[34] MASMI (2015). E-business development: Study on motivators and barriers for online shopping of e-consumers in Serbia (in Serbian). Research within the IPA project Ebusiness development. (n.d.). Retrieved from http://eposlov anje.biz/CMS/Izvestaj_Razvoj e-poslovanja - MASMI Beo grad.pdf

[35] SORS (2015). Statistical Database, Usage of IC technologies. Statistical Office of the Republic of Serbia. (in Serbian) (n.d.). Retrieved from http://webrzs.stat.gov.rs/ WebSite/public/ReportView.aspx

[36] Kumar, N., Stern, L. W., \& Anderson, J. C. (1993). Conducting Interorganizational Research Using Key Informants. Academy of Management Journal, 36(6), 16331651. https://doi.org/10.2307/256824
[37] Fassnacht, M. \& Koese, I. (2006). Quality of Electronic Services: conceptualizing and testing a hierarchical model. Journal of Service Research, 9(1), 19-37. https://doi.org/10.1177/1094670506289531

[38] Ladhari, R. (2008). Alternative measures of service quality: A review. Managing Service Quality: An International Journal, 18(1), 65-86. https://doi.org/10.1108/09604520810842849

[39] Green, S. B., Salkind, N. J., \& Akey, T. M. (2000). Using SPSS for Windows: Analyzing and understanding data. Upper Saddle River, NJ: Prentice Hall.

[40] Nunnally, J. C. \& Bernstein, I. H. (2010). Psychometric theory. New Delhi: Tata McGraw-Hill Ed.

[41] Gerbing, D. W. \& Anderson, J. C. (1988). An Updated Paradigm for Scale Development Incorporating Unidiensionality and Its Assessment. Journal of Marketing Research, 25(2), 186-192. https://doi.org/10.1177/002224378802500207

[42] Maditinos, D. I. \& Theodoridis, K. (2010). Satisfaction determinants in the Greek online shopping context. Information Technology \& People, 23(4), 312-329. https://doi.org/10.1108/09593841011087789

[43] Rudansky-Kloppers, S. (2014). Investigating Factors Influencing Customer Online Buying Satisfaction in Gauteng, South Africa. International Business \& Economics Research Journal (IBER), 13(5), 1187. https://doi.org/10.19030/iber.v13i5.8784

[44] Chun, C. L., Hsueh-Ying, Y. W., \& Yong, F. C. (2011). The critical factors impact on online customer satisfaction. Procedia Computer Science, 3, 276-281. https://doi.org/10.1016/j.procs.2010.12.047

\section{Contact information:}

Tanja KAURIN, Assistant professor

(Corresponding author)

Faculty of Law and Business Studies,

Bulevar oslobođenja 76, 21000 Novi Sad, Serbia

E-mail:mtanja@gmail.com

Aleksandar BOŠKOVIĆ, Assistant professor

Faculty of Technical Sciences,

Trg Dositeja Obradovića 6, 21000 Novi Sad, Serbia

E-mail: aboskovic@uns.ac.rs 